\title{
Shelf Life and Heavy Metals Study of Two Common Edible Insects in Ijebu Division, Southwestern, Nigeria
}

\author{
Banjo A. D. \\ Department of Plant Science and Applied Zoology \\ Olabisi Onabanjo University, Ago-Iwoye, P.M.B. 2002, Nigeria \\ Tel: 234-807-617-6961Ｅ-mail: adaba55@yahoo.co.uk
}

\begin{abstract}
Aina S. A. (Corresponding author)
Department of Plant Science and Applied Zoology

Olabisi Onabanjo University, Ago-Iwoye, P.M.B. 2002, Nigeria

Tel: 234-805-615-4796_E-mail: diplomataina@yahoo.com
\end{abstract}

Salau A. R.

Department of Plant Science and Applied Zoology

Olabisi Onabanjo University, Ago-Iwoye, P.M.B. 2002, Nigeria

Tel: 234-805-093-6706 E-mail: richardsalau007@tahoo.com

Received: August 10, 2012 Accepted: September 2, 2012

doi:10.5296/jbls.v4i1.2251 URL: http://dx.doi.org/10.5296/jbls.v4i1.2251

\begin{abstract}
The shelf life and heavy metal contaminants of two commonly available edible insects in Ijebu division of Ogun State, Nigeria were studied. The samples were collected through water trap and by handpicking respectively with a view of adopting the method of the Association of Official Analytical Chemists for the shelf life and heavy metal study. Heavy metal contaminants such as Cadmium $(10.95 \mathrm{mg} / \mathrm{kg}, 12.70 \mathrm{mg} / \mathrm{kg})$, Zinc $(5.50 \mathrm{mg} / \mathrm{kg}, 2.70 \mathrm{mg} / \mathrm{kg})$ and Lead $(39.55 \mathrm{mg} / \mathrm{kg}, 40.15 \mathrm{mg} / \mathrm{kg}$ ) respectively, were revealed in both insects. After three months of storage, the results showed that there was high depreciation in the nutritional components in both Rhynchophorus phoenicis (larva) and Macrotermes bellicosus (winged). Therefore, this insinuates an $80 \%$ reduction in the nutritional composition it can supply when
\end{abstract}


consumed after three months of storage. The need to study further adequate methods of extending their shelf life is of utmost importance.

Keywords: Edible insects, Shelf life, Heavy metal, Rhynchophorus phoenicis, Macrotermes bellicosus.

\section{Introduction}

Edible insects are important dietary components in many developing countries. Insects commonly consumed include locusts, termites, grasshoppers, weevils and various caterpillars as stated by Ene, (1963). Many studies have also shown that edible insects contain appreciable amounts of nutritional sources such as proteins and high fibre. Infact, they have also been found to be rich sources of fat, vitamins and minerals, especially Iron and Zinc as suggested by Malaisse and Parent, (1980).

As a result of this, further information about the people's knowledge, perception and attitude to common edible insects in Ijebu division of Ogun State as well as the nutritional values were carried out to source for information about insects being eaten in this part of the country. This initiated the use of questionnaires to collect data from the respondents.

The term shelf life is the length of time that food, drink, medicine, chemicals, and many other perishable items are given before they are considered unsuitable for sale, use, or consumption. Shelf life is also the recommendation of time that products can be stored, during which the defined quality of a specified proportion of the product remains acceptable under expected or specified conditions of distribution, storage and display (Anon, 2003).

These edible insects are an excellent source of protein, calcium, vitamins and minerals, and they even contain more healthy polyunsaturated fat than fish or fowl. One hundred grams of dried fly is made up of 54 grams of protein, almost 50 milligrams of iron and important quantities of essential amino acids and B vitamins (Anon, 2010).

Insects have been a staple of almost every indigenous culture, not only because they provide a more complete protein than soya meat or fish and have high concentrated sources of Calcium, Niacin, Magnesium, Potassium, the B-vitamins and many other nutrients (Anon, 2005). Furthermore, Nigerian researchers have found out that edible insects constitute an important part of the daily diet of a large proportion of the population in South-Western Nigeria (Banjo et al., 2006).

The objective of the study is to investigate the period of time that the nutritional composition of the two edible insects (Rhynchophorus phoenicis and Macrotermes bellicosus) can still remain intact and also the heavy metal contamination or composition found in them.

\section{Materials and Methods}

\subsection{Collection of Edible Insects}

The various methods used for collecting the edible insects included handpicking for Rhynchophorus phoenicis (larva) and Water Trap: Bowl of water put under a fluorescent lamp for Macrotermes bellicosus (winged). The collections were conducted in the Six Local 


\section{MInstitute Macrothink $_{\text {Int }}$}

Government Areas of Ijebu division of Ogun State. The areas visited include eighteen towns. They were:

- Ijebu North: Ago-Iwoye, Oru, Ijebu- Igbo.

- Ijebu North East: Atan, Isonyin, Eruwon.

- Ijebu ode: Ijebu-ode, Imagbon, Igbeba.

- Ogun Waterside: Abigi, Ibiade, Iwopin.

- Odogbolu: Odogbolu, Erinla, Ayepe.

- Ijebu East: Ijebu-Imushin, Ijebu-Ife, Ogbere.

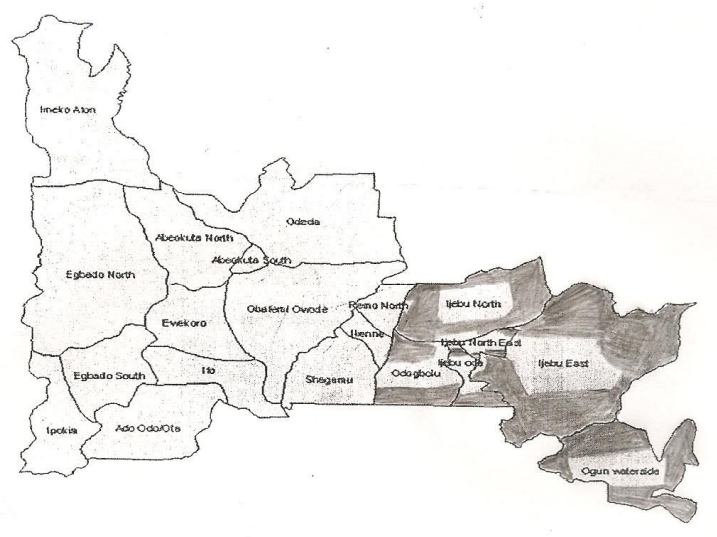

Figure 1. The Map of Ogun State showing the Collection areas.
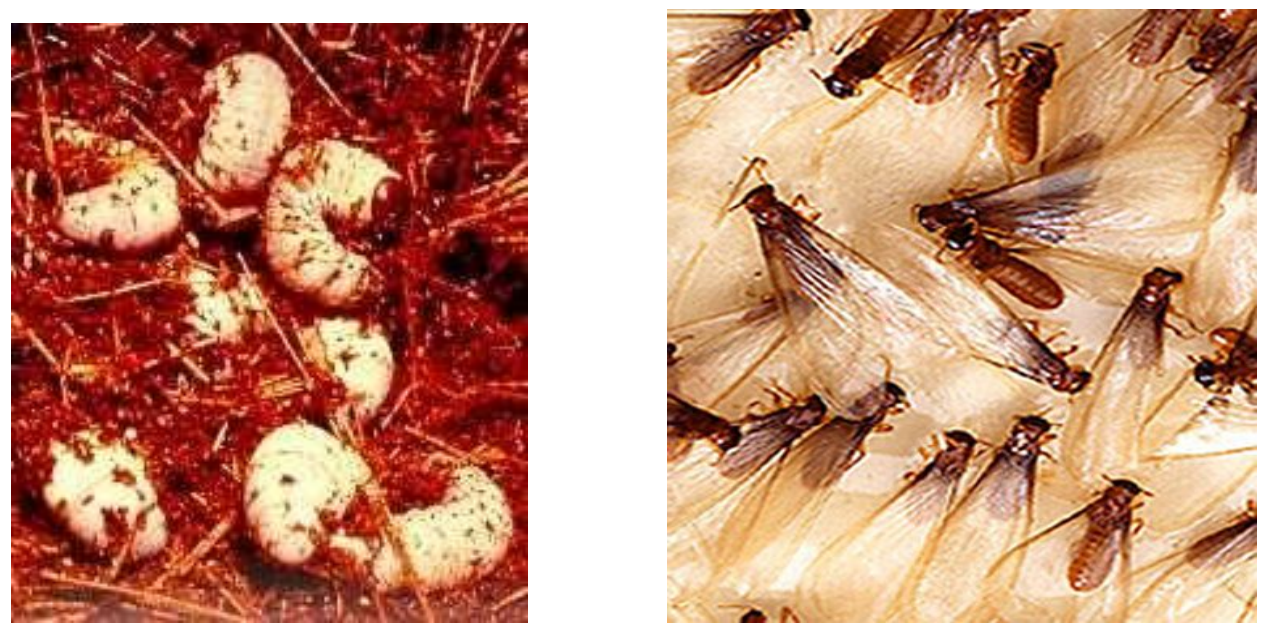

Figure 2. Larvae of Rhynchophorus phoenicis Figure 3. Winged (reproductive) adults of Termite

\subsection{Heavy Metal Contaminants}

The methods and techniques adopted for the analysis of Rhynchophorus phoenicis larvae and Macrotermes bellicosus (winged termite) are that of the Association of Official Analytical Chemists, (AOAC, 2003). This analysis determined the level of metal concentration in the 


\section{MInstitute Macrothink $_{\text {Intion }}$}

specimens. These metals included; Zinc (Zn), Cadmium (Cd) and Lead (Pb).

\section{Results}

The result of the proximate analysis for both insect species revealed that the percentage of crude protein's initial reading in $R$. phoenicis (larva) differed from the reading at the end of the third month showing $64.15 \%-63.14 \%$ while that of M. bellicosus (winged) showed a decrease from $50.17 \%-47.08 \%$. The differences cut across all the other parameters with the initial calorie value reading in $R$. phoenicis (larva) showing $20.0 \mathrm{Kcal} / \mathrm{kg}-19.0 \mathrm{Kcal} / \mathrm{kg}$ and $M$. bellicosus (winged) showed $21.2 \mathrm{Kcal} / \mathrm{kg}-21.23 \mathrm{Kcal} / \mathrm{kg}$.

Table 1. Proximate composition (Initial reading) freshly caught.

\begin{tabular}{|c|c|c|c|c|c|c|c|c|}
\hline Specimens & $\begin{array}{l}\text { Crude } \\
\text { protein } \\
(\%)\end{array}$ & $\begin{array}{l}\text { Crude } \\
\text { fat } \\
(\%)\end{array}$ & $\begin{array}{l}\text { Crude } \\
\text { fibre } \\
(\%)\end{array}$ & $\begin{array}{l}\text { Carbohydrate } \\
(\%)\end{array}$ & $\begin{array}{l}\text { Moisture } \\
\text { content } \\
(\%)\end{array}$ & $\begin{array}{l}\text { Total } \\
\text { Ash } \\
(\%)\end{array}$ & $\begin{array}{l}\text { Calorie } \\
\text { value } \\
\text { (Kcal/kg) }\end{array}$ & $\begin{array}{l}\text { Dry } \\
\text { matter } \\
(\%)\end{array}$ \\
\hline $\begin{array}{l}\text { Rhynchophorus } \\
\text { phoenicis (larva) }\end{array}$ & 64.15 & 9.20 & 23.99 & 1.70 & 9.60 & 38.11 & 20.05 & 90.40 \\
\hline $\begin{array}{l}\text { Macrotermes } \\
\text { bellicosus } \\
\text { (winged) }\end{array}$ & 50.17 & 25.70 & 18.73 & 1.99 & 8.40 & 33.51 & 21.27 & 91.60 \\
\hline
\end{tabular}

Table 2. Proximate composition (after 3 months of storage)

\begin{tabular}{|l|l|l|l|l|l|l|l|l|}
\hline Specimens & $\begin{array}{l}\text { Crude } \\
\text { protein } \\
(\boldsymbol{\%})\end{array}$ & $\begin{array}{l}\text { Crude } \\
\mathbf{f a t} \\
(\boldsymbol{\%})\end{array}$ & $\begin{array}{l}\text { Crude } \\
\mathbf{f i b r e} \\
(\boldsymbol{\%})\end{array}$ & $\begin{array}{l}\text { Carbohydrate } \\
(\boldsymbol{\%})\end{array}$ & $\begin{array}{l}\text { Moisture } \\
\text { content } \\
(\boldsymbol{\%})\end{array}$ & $\begin{array}{l}\text { Total } \\
\text { Ash } \\
(\boldsymbol{\%})\end{array}$ & $\begin{array}{l}\text { Calorie } \\
\text { value } \\
(\mathbf{K c a l} / \mathbf{k g})\end{array}$ & $\begin{array}{l}\text { Dry } \\
\text { matter } \\
(\boldsymbol{\%})\end{array}$ \\
\hline $\begin{array}{l}\text { Rhynchophorus } \\
\text { phoenicis (larva) }\end{array}$ & 63.14 & 8.19 & 21.99 & 1.65 & 9.35 & 37.34 & 19.05 & 90.65 \\
\hline $\begin{array}{l}\text { Macrotermes } \\
\text { bellicosus } \\
\text { (winged) }\end{array}$ & 47.08 & 22.45 & 15.82 & 1.82 & 7.46 & 31.83 & 21.23 & 92.54 \\
\hline
\end{tabular}

The result of the vitamin analysis in both species revealed that the percentage of Vitamin B1 in $R$. phoenicis (larva) at the initial and after three months of storage showed a difference of $0.20 \%-0.18 \%$ while that of $M$. bellicosus (winged) showed a difference of $0.39 \%-0.21 \%$. The same differences were noticed amongst the other parameters such as Vitamin B2, B3, B5, B6, B7, B9, B12, A, C, D, E and K.

Table 3. Vitamin composition

\begin{tabular}{|c|c|c|c|c|}
\hline \multirow[t]{2}{*}{ Vitamins } & \multicolumn{2}{|c|}{$\begin{array}{l}\text { R.phoenicis (larva) } \\
(\%)\end{array}$} & \multicolumn{2}{|c|}{ M. bellicosus (winged) (\%) } \\
\hline & Initial reading & $\begin{array}{ll}\text { After } & 3 \\
\text { months }\end{array}$ & $\begin{array}{l}\text { Initial } \\
\text { reading }\end{array}$ & $\begin{array}{ll}\text { After } & 3 \\
\text { months }\end{array}$ \\
\hline VitaminB1 (Thiamin) (mg/100g) & 0.20 & 0.18 & 0.39 & 0.21 \\
\hline VitaminB2 (Riboflavin) (mg/100g) & 0.15 & 0.11 & 0.15 & 0.07 \\
\hline Vitamin B3 (Niacin) (mg/100g) & 1.96 & 1.86 & 1.79 & 1.74 \\
\hline $\begin{array}{lll}\text { VitaminB5 } & \text { (Pantothenic } & \text { acid }) \\
(\mathrm{mg} / 100 \mathrm{~g}) & & \end{array}$ & 0.94 & 0.89 & 1.00 & 0.95 \\
\hline VitaminB6 (Pyridoxine) (mg/100g) & 2.50 & 2.34 & 2.60 & 2.47 \\
\hline Vitamin B7 (Biotin) (mg/100g) & 0.50 & 0.38 & 0.59 & 0.54 \\
\hline Vitamin B9 (Folic acid) (mg/100g) & 0.74 & 0.67 & 0.90 & 0.82 \\
\hline $\begin{array}{lll}\begin{array}{l}\text { Vitamin } \\
(\mathrm{mg} / 100 \mathrm{~g})\end{array} & \text { B12 } & \text { (Cyanocobalamin) } \\
\end{array}$ & 0.38 & 0.31 & 0.23 & 0.19 \\
\hline Vitamin A $(\mu g / 100 g)$ & 3150.3 & 3128.2 & 3112.2 & 3096.2 \\
\hline VitaminC (mg/100g) & 1.74 & 1.61 & 2.48 & 2.34 \\
\hline VitaminD $(\mu \mathrm{g} / 100 \mathrm{~g})$ & 47.85 & 46.28 & 41.99 & 41.34 \\
\hline Vitamin $E(\mu \mathrm{g} / 100 \mathrm{~g})$ & 135.7 & 133.4 & 128.9 & 128.3 \\
\hline Vitamin K $(\mu \mathrm{g} / 100 \mathrm{~g})$ & 18.01 & 17.86 & 15.03 & 14.69 \\
\hline
\end{tabular}


The result of heavy metal contaminants revealed a significant difference in both edible insect species. In $R$. phoenicis (larva), Cadmium readings varied between $11.7 \mathrm{mg} / \mathrm{kg}-10.95 \mathrm{mg} / \mathrm{kg}$ within the first and after three months of study while $M$. bellicosus also differed in Cadmium readings $13.10 \mathrm{mg} / \mathrm{kg}-12.70 \mathrm{mg} / \mathrm{kg}$. The same difference was revealed in other parameters such as Zinc and Lead.

Table 4. Heavy metal contamination

\begin{tabular}{|c|c|c|c|c|}
\hline \multirow[t]{2}{*}{ Minerals } & \multicolumn{2}{|l|}{ R. phoenicis } & \multicolumn{2}{|l|}{ M. bellicosus } \\
\hline & 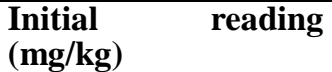 & $\begin{array}{l}\text { After } \\
(\mathrm{mg} / \mathrm{kg})\end{array} \quad$ months & $\begin{array}{ll}\begin{array}{l}\text { Initial } \\
(\mathrm{mg} / \mathrm{kg})\end{array} & \text { reading } \\
\end{array}$ & $\begin{array}{lll}\begin{array}{l}\text { After } \\
(\mathrm{mg} / \mathrm{kg})\end{array} & 3 & \text { months } \\
\end{array}$ \\
\hline Cadmium & 11.70 & 10.95 & 13.10 & 12.70 \\
\hline Zinc & 5.70 & 5.50 & 2.90 & 2.70 \\
\hline Lead & 41.60 & 39.55 & 42.18 & 40.15 \\
\hline
\end{tabular}

\section{Discussion and Conclusion}

The moisture content is an index of water activity (Olutiola et al., 1991) and susceptible to microbial contamination (Uraih and Izuagbe, 1990). Consequently, the percentage moisture value obtained proved that the shelf life of M. bellicosus (winged) and $R$. phoenicis (larva) can be extended for a reasonable period of time without the risk of microbial deterioration and spoilage if properly dehydrated. This was due to the drying method (sun drying) adopted before the analysis for nutritional elements (proximate) was carried out.

After three months of study, the two edible species $R$. phoenicis (larva) and M. bellicosus (winged) which showed considerable levels of nutritional sources had a significant drop in the nutritional values as against the initial values. This suggests why mass people in the study area consumed the insects within a period of three days because they were still fresh and the nourishment intact. According to a personal interview with the hawkers of these edible insects, it was confirmed that since the insects are perishable, the only way of preserving them for a long period is to dry and pack them. In this packed form, they would be useful addictives to food such as ogi (pap) for weaning children.

However, a considerable amount of heavy metal contaminants such as Lead, Cadmium and Zinc were detected in both species. This contamination is assumed by Anon, (2004) to be due to Cadmium waste released from nearby refinery or mining factories through airborne medium, falling onto the insect body surfaces and also the wrong application of chemical pesticides near the habitats of these two species. The implication of this is that it can severely damage the lungs, the immune system and can cause psychological disorder (Anon, 2004).

Therefore, the sustainability of edible insects includes that there should be laws enacted to barn the indiscriminate destruction of forests as this could lead to an extinction of these valuable source of food. Artificial rearing of these insects can also improve its abundance throughout the year. Afforestation or planting of oil palm tree should be encouraged as this could improve the reproductive cycle of $R$. phoenicis (larva) and make their population increase during its season. In relation to the heavy metals contaminant, it is suggested that factories be sited far away from the habitats of these edible species. More enlightenment programmes should be organized to educate the populace about the economic advantages of consuming these insects. 


\section{Mll Macrothink}

\section{References}

A. O. A. C. (Association of Official Analytical Chemists). (2003). Official Methods of Analysis of AOAC International. 17th edition. 2nd revision. Gaithersburg, MD, USA. 1141.

Anon. (2003). The Shelf-Life Program. Shelf-Life Management Manual - Definitions. www.en-wikipedia.com. (Retrieved 14th February, 2012).

Anon, (2004). Lead and Human Health. (Retrieved 25th March, 2012).http://www.hc-sc.gc.ca/hl-vs/iyh-vsv/environ/lead-plomb-eng.php.

Anon. (2010). Edible insects in Mexico. http://dfdeath.blogspot.com/2010/08/edible-insects-in-mexico.html.

Banjo, A. D., Lawal, O. A., \& Songonuga, E. A. (2006). The nutritional value of fourteen species of edible insects in Southwestern Nigeria. African Journal of Biotechnology, 5(3), 298-301.

Ene, J. C. (1963). Insects and man in West Africa. Ibadan University Press, Ibadan. 42.

Malaisse, F., \& Parent, G. (1980). Les Chenicles comestibles du shaba meridional (Zaire) naturalistes Beiges, Journal of Nutrition, 61, 2-24.

Olutiola, P. O., Famurewa O., \& Sonntag H.G. (1991). An Introduction to General Microbiology, A Practical Approach. 1st Edition. Heidelberger Verlagsanstalt and Druckerei GmbH Heidelberg, Germany, ISBN: 3-894-042-4.

Olutiola, P. O., Famurewa, O., \& Sonntag, H. G. (1991). An introduction to general microbiology, a practical approach. 1st Edition. Heidelberger Verlagsanstalt and Druckerei GmbH Heidelberg, Germany, ISBN: 3-894-042-4.

Uraih, N., \& Izuagbe, Y. (1990). Public Health, Food and Industrial Microbiology. 1st Edition, UNIBEN Press: Nigeria. ISBN: 978-2027-00-6.

\section{Copyright Disclaimer}

Copyright reserved by the author(s).

This article is an open-access article distributed under the terms and conditions of the Creative Commons Attribution license (http://creativecommons.org/licenses/by/3.0/). 